\title{
Calcipotriol inhibits rectal epithelial cell proliferation in ulcerative proctocolitis
}

\author{
M G Thomas, K P Nugent, A Forbes, R C N Williamson
}

\begin{abstract}
Vitamin $D_{3}$ reduces human rectal crypt cell production rate (CCPR) and may thereby protect against colorectal cancer. Cell turnover is increased in ulcerative proctocolitis, which might therefore respond to vitamin $D_{3}$ metabolites. This study investigated the effect of calcipotriol, a synthetic vitamin $D_{3}$ analogue that avoids hypercalcaemia, on human rectal CCPR in ulcerative proctocolitis. Paired rectal biopsy specimens from seven patients with severe disease were established in organ culture with or without calcipotriol $\left(1 \times 10^{-6} \mathrm{M}\right)$. After 15 hours, vincristine $(0.6 \mu \mathrm{g} / \mathrm{ml})$ was added to induce metaphase arrest, and CCPR was determined by linear regression analysis of accumulated metaphases. Compared with values in 17 controls with incidental anal conditions, median rectal CCPR was $28 \%$ higher in ulcerative proctocolitis: $\quad 5.90 \quad(5.00-9 \cdot 50) \quad v \quad 4.80$ (2.85-7.07) cells/crypt/hour $(\mathbf{p}<0.01)$. Calcipotriol reduced CCPR by $62 \%$ in patients with ulcerative proctocolitis, from $5.90(5.00-9.50)$ to $2.21(0.81-3.22)$ cells/crypt/hour (median with range) $p<0.01$. Thus calcipotriol can dampen the hyperproliferative state in ulcerative proctocolitis and could have a therapeutic role in the control of this inflammatory condition.
\end{abstract}

(Gut 1994; 35: 1718-1720)

In normal rectal epithelium static measurements of cell proliferation suggest that the proliferative compartment is confined to the lower third of the crypt, but in ulcerative proctocolitis there is a two to threefold expansion of this compartment. ${ }^{1-4} \mathrm{~A}$ more dynamic method using the stathmokinetic technique of metaphase arrest shows that cell birth (crypt cell production rate, (CPR) is increased in both active and quiescent ulcerative proctocolitis. ${ }^{5}$ There is increasing evidence that accelerated cell proliferation in the large bowel predisposes to malignancy, and this may help to explain the correlation between the extent and chronicity of colitis and the subsequent risk of developing carcinoma. ${ }^{5-9}$

Epidemiological evidence shows that vita$\min D_{3}$ can protect against colorectal cancer. ${ }^{10}$ The vitamin D receptor is expressed in both normal ${ }^{11}$ and malignant colorectal epithelial cells. ${ }^{12-14}$ The active form of the vitamin, 1,25 $(\mathrm{OH})_{2} \mathrm{D}_{3}$, also reduces in vitro CCPR in colorectal cell lines, normal rectal tissue, and tissue from familial adenomatous polyposis patients. ${ }^{15}$ Although the clinical use of 1,25 $(\mathrm{OH})_{2} \mathrm{D}_{3}$ is severely limited by its profound effects on calcium metabolism, synthetic vitamin $\mathrm{D}_{3}$ metabolites can avoid these hypercalcaemic and hypercalciuric effects. ${ }^{15} 16$ One such metabolite is calcipotriol, ${ }^{16}{ }^{17}$ which also reduces in vitro epithelial cell proliferation (CCPR) in normal human rectal tissue and malignant colorectal cells. ${ }^{15} \mathrm{We}$ have therefore investigated the effect of calcipotriol on in vitro rectal epithelial cell proliferation in ulcerative proctocolitis using a stathmokinetic technique to measure CCPR.

\section{Methods}

\section{CHEMICALS}

The secosterol calcipotriol (MC-903) was supplied by Leo Pharmaceutical Products (Ballerup, Denmark) and stored in isopropyl alcohol at $-20^{\circ} \mathrm{C}$ until use. Control medium was prepared with a similar dilution of alcohol, which had no detectable effect on proliferation. ${ }^{15}$ Vincristine (Oncovin) was supplied by Eli Lilly (Basingstoke, UK). The standard culture medium consisted of CMRL 1066 (GIBCO, Paisley, UK), 5\% fetal calf serum, $100 \mathrm{U} / \mathrm{ml}$ penicillin, and $100 \mu \mathrm{g} / \mathrm{ml}$ streptomycin, $2 \%$ L-glutamine $(200 \mathrm{mM})$ and $1 \%$ HEPES buffer $1 \mathrm{M}$ (all from Sero Labs, Crawley, UK). Glucose $20 \mathrm{mg}$, hydrocortisone 21-hemisuccinate $1 \mathrm{mg}$, and insulin $1 \mathrm{mg}$ (Sero Labs, Crawley, UK) were added to each $20 \mathrm{ml}$ of culture medium immediately before each experiment. ${ }^{15} 18$

\section{CLINICAL MATERIAL}

Paired rectal biopsy specimens were taken from seven patients with longstanding ulcerative proctocolitis of moderate to severe activity at routine follow up proctosigmoidoscopy. There were five men and two women, with a median age of 43 years (range 34-80); all the patients were being treated with corticosteroid enemas and an oral 5-aminosalicylate. Two patients had extensive colitis and five had more distal disease. One specimen from each patient was examined histologically (as part of their routine treatment) while the other was set up in organ culture. Local ethical committee approval was obtained, and all patients gave fully informed consent.

\section{ORGAN CULTURE}

The rectal biopsy specimens were divided into numerous explants and orientated with the 
Crypt cell production rate (cells/crypt/hour)

\begin{tabular}{lll}
\hline & Control & Calcipotriol $\left(1 \times 10^{-6} \mathrm{M}\right)$ \\
\hline & $5 \cdot 42(0.76)$ & $1 \cdot 11(0.54)$ \\
$9 \cdot 50(1.27)$ & $3.19(0.98)$ \\
$5 \cdot 00(0.56)$ & $3.22(0.31)$ \\
& $5 \cdot 90(0.56)$ & $2 \cdot 21(0.28)$ \\
& $6 \cdot 10(1.34)$ & $1.63(0.04)$ \\
& $9 \cdot 16(0.67)$ & $2 \cdot 25(0.86)$ \\
& $5 \cdot 00(0.32)$ & $0.81(0.94)$ \\
Mean & $6 \cdot 58(0.73)$ & $2 \cdot 06(0.94)$ \\
Median (range) & $5.90(5.00-9 \cdot 50)$ & $2 \cdot 21(0.81-3.22)^{\star}$
\end{tabular}

^Experiment $v$ control $\mathrm{p}<0 \cdot 01$. Values are mean (SEM).

mucosal surface uppermost on a metal grid within an organ culture dish (Lux Laboratories). Explants from each patient were cultured as paired samples (control and experimental) in standard culture medium (CMRL 1066, Gibco, Paisley, UK) or in standard culture medium to which $1 \times 10^{-6} \mathrm{M}$ calcipotriol had been added. This dose of calcipotriol has provisionally been shown to reduce CCPR in tissue taken from patients with familial adenomatous polyposis ${ }^{19}$ and is slightly higher than that which reduces CCPR in normal rectal tissue. ${ }^{15}$ The organ culture dishes were sealed in an atmosphere of $95 \% \mathrm{O}_{2}$ and $5 \% \mathrm{CO}_{2}$ at a temperature of $37^{\circ} \mathrm{C}$ and were rocked at five cycles per minute. After 15 hours, vincristine $(0 \cdot 6 \mu \mathrm{g} / \mathrm{ml})$ was added to the culture medium to produce metaphase arrest within the colonic crypts. Explants were sequentially removed one, two, and three hours later, were fixed in Carnoy's fluid, and then stored in $70 \%$ alcohol. Explants were rehydrated in solutions of $50 \%, 25 \%$, and $10 \%$ alcohol. After acid hydrolysis in $1 \mathrm{M} \mathrm{HCl}$ at $60^{\circ} \mathrm{C}$ for six minutes, the tissue was stained with Schiff's reagent. At least 20 crypts were microdissected from each explant, and the number of metaphases per crypt was counted. The mean number of metaphases was plotted against the time from vincristine administration, and the crypt cell production rate was determined by least squares linear regression analysis, giving a value for the crypt cell production rate in cells/crypt/hour..$^{15182021}$ Explants showing evidence of infection or crypt necrosis were discarded.

\section{Results}

Cultured tissue showed a good preservation of architecture with an infection and crypt necrosis rate of $2 \%$, in line with our previous results. ${ }^{1521}$ There was no evidence of metaphase escape in any of the microdissected crypts, which implies that the dose of vincristine used was sufficient to produce complete metaphase arrest. In addition the crypts appeared intact. Histological examination confirmed the presence of active colitis in all samples with no evidence of dysplasia in any of the specimens. The overall median control CCPR was 5.90 cells/crypt/hour (range 5.00-9.50 cells/crypt/hour). This value is lower than that reported by Allan et $a l,{ }^{5}$ but when compared with our previous control values (mean (SEM) 4.74 (0.25), median $4 \cdot 80$ range $2 \cdot 85-7 \cdot 07$ cells/crypt/hour) in patients with incidental anal conditions, ${ }^{15}$ it represents a $28 \%$ increase in CCPR $(p<0.01$ Mann-Whitney U test).

CCPR was reduced in all explants cultured with calcipotriol when compared with their own control (Table). The overall median CCPR was reduced by $62 \%$ from 5.90 $(5 \cdot 00-9 \cdot 50)$ to $2 \cdot 21 \quad(0 \cdot 81-3 \cdot 22)$ cells/crypt/hour $(\mathrm{p}<0.01$ Mann-Whitney U test).

\section{Discussion}

We have shown, for the first time, that a synthetic vitamin $\mathrm{D}_{3}$ metabolite (calcipotriol) reduces rectal epithelial cell proliferation in tissue taken from patients with active ulcerative proctocolitis. Calcipotriol reduced CCPR by about $60 \%$, to a value well below that seen in our previously reported controls. ${ }^{15}$ These findings are in keeping with the well reported anti-proliferative effects of 1,25 $(\mathrm{OH})_{2} \mathrm{D}_{3}{ }^{12-15}$ and show that colorectal tissue in inflammatory bowel disease retains its ability to respond to vitamin $\mathrm{D}_{3}$ metabolites. We have previously reported a similar effect of both $1,25(\mathrm{OH})_{2} \mathrm{D}_{3}$ and calcipotriol on normal rectal tissue, ${ }^{15}$ but we could not show a clear cut dose response effect in organ culture. There was no microscopic evidence to suggest that the observed effect in this experiment resulted from calcipotriol induced toxicity; indeed, the linear accumulation of metaphases seen in our experimental group suggests that the tissue was healthy and retained its ability to proliferate.

Ulcerative proctocolitis is associated with a hyperproliferative colorectal epithelium. ${ }^{1-5}$ There is an expansion or a major shift of the proliferative compartment in active and quiescent disease, and an altered cytokinetic state is retained after total abdominal colectomy with ileorectal anastomosis. ${ }^{522}$ The accelerated rate of cell proliferation might contribute to the observed increase in incidence of large bowel cancer in ulcerative proctocolitis. Indeed, the distribution of mutations in dysplastic colitic tissue suggests that dysplastic fields might originate by clonal proliferation from a single cell containing mutations. ${ }^{23} \mathrm{~A}$ reduction in the rate of cell proliferation or an induction of differentiation in longstanding disease using synthetic vitamin D analogues might protect against the subsequent development of colorectal carcinoma. In addition, synthetic metabolites might offer a therapeutic option in the control of disease in those patients who relapse with corticosteroid and aminosalicylate treatment.

The topical administration of calcipotriol has a dramatic effect in psoriasis vulgaris, ${ }^{24-26}$ but it is not at present available for enteric use; its short half life may limit its oral or rectal therapeutic use. ${ }^{17}$ It is not yet known whether a reduction in colorectal epithelial cell proliferation would control symptoms in ulcerative proctocolitis or whether this would have a beneficial effect on the disease process.

We did not measure serum concentrations of calcium or vitamin $D_{3}$ metabolites or the 
release of cytokines from the tissue. Vitamin $\mathrm{D}_{3}$ metabolites can inhibit the proliferation of peripheral blood lymphocytes. ${ }^{27}$ Cellular activation of peripheral blood $\mathrm{T}$ lymphocytes by antigen or lectin is accompanied by synthesis of the vitamin $\mathrm{D}$ receptor, ${ }^{28}{ }^{29}$ and the reduction in proliferation of these cells by $1,25(\mathrm{OH})_{2} \quad \mathrm{D}_{3}$ has been correlated with a decreased production of interleukin $2 .{ }^{30} 31$

It is known that some of the differentiating effects of $1,25(\mathrm{OH})_{2} \quad \mathrm{D}_{3}$ are associated with a modulation of vitamin $\mathrm{D}$ receptor expression, ${ }^{29} 32$ but, vitamin $\mathrm{D}$ receptor expression has not yet been reported in colorectal tissue from patients with ulcerative proctocolitis. Calcipotriol clearly reduces in vitro CCPR in ulcerative proctocolitis, but more sophisticated methods will be required to determine the intracellular events responsible for the effect of vitamin $\mathrm{D}_{3}$ and its metabolites on human colorectal epithelial cell proliferation.

1 Bleiberg H, Mainguet P, Galand P, Chretien J, DupondMairesse $\mathrm{N}$. Cell renewal in the human rectum. In vivo autoradiography study on active ulcerative colitis. Gastroenterology 1970; 58: 851-5.

2 Eastwood LG, Trier JS. Epithelial cell renewal in cultured rectal biopsies in ulcerative colitis. Gastroenterology 1973; 64: 383-90.

3 Serafini EP, Kirk AP, Chambers TJ. Rate and pattern of epithelial cell proliferation in ulcerative colitis. Gut 1981; 22: 648-52.

4 Franklin WA, McDonald GB, Stein HO, Gatter KC, Jewell DP, Clarke LC, et al. Immunohistological demonstration of abnormal colonic crypt kinetics in ulcerative colitis. Hum Pathol 1985; 16: 1129-32.

5 Allan A, Bristol JB, Williamson RCN. Crypt cell production rate in ulcerative proctocolitis; differential increments in remission and relapse. Gut 1985; 26: 999-1003.

6 Lipkin M. Biomarkers of increased susceptability to gastrointestinal cancer: new applications of studies of cancer prevention in human subjects. Cancer Res 1988; 48: $235-45$.

7 Rainey JB, Davies PW, Williamson RCN. Relative effects of ileal resection and bypass on intestinal adaptation and carcinogenesis. Br $\mathcal{F}$ Surg 1984; 71: 197-202.

8 Hinton JM. Risk of malignant change in ulcerative proctocolitis. Gut 1968; 7: 427-32.

9 Gyde SN, Prior P, Allan RN, Stevens D. Colorectal cancer in ulcerative colitis: a cohort study of primary referrals from three centres. Gut 1988; 29: 206-17.

10 Garland C, Barrett-Conner ER, Shekelle RB, Crique MM, Paul O. Dietary vitamin D and calcium and risk of colorectal cancer. Lancet 1985; i: 307-9.

11 Lointier P, Meggouh F, Dechelotte P, Pezet D, Ferrier Ch, Chipponi J, et al. 1,25 Dihydroxy vitamin $\mathrm{D}_{3}$ receptors and human colon adenocarcinoma. Br f Surg 1991; 78: and hum 93 .

12 Harper KD, Iozzo RV, Haddad JG. Receptors for and bioresponses to 1,25 dihydroxy vitamin $\mathrm{D}$ in a human colon carcinoma cell line (HT-29). Metabolism 1989; 38: 1062-9.
13 Brehier A, Thomasset M. Human colon cell line HT-29 characterisation of 1,25 dihydroxyvitamin $D_{3}$ receptor and induction of differentiation by the hormone. F Steroid Biochem 1988; 29: 265-70.

14 Lointier P, Wargovich MI, Saez S, Levin B, Wildrick DM, Boman BM. The role of vitamin $\mathrm{D}_{3}$ in the proliferation of a human cancer cell line in-vitro. Anticancer Res 1987; 7: 817-22.

15 Thomas MG, Tebbutt S, Williamson RCN. Vitamin D and its metabolites inhibit cell proliferation in human rectal mucosa and a colon cancer cell line. Gut 1992; 33: 1660-3.

16 Binderup L, Bramm E. Effects of a novel vitamin D analogue $\mathrm{MC}-903$ on cell proliferation and differentiation in-vitro and on calcium metabolism in-vivo. Biochem Pharmacol 1988; 37: 889-95.

17 Binderup L, Latini S, Binderup E, Bretting C, Calverley $M$, Hansen K. 20-Epi-vitamin D analogues: a novel class of potential regulators of cell growth and immune responses. Biochem Pharmacol 1991; 42: 1569-75.

18 Appleton GVN, Wheeler EE, Al-Mufti R, Challacombe DN, Williamson RCN. Rectal hyperplasia after jejunioleal bypass for morbid obesity. Gut 1988; 29: 1544-8.

19 Thomas MG, Williamson RCN. Inhibition of colorectal cell proliferation by vitamin D analogues [Abstract]. Br f Surg 1992; 79: 1233 .

20 Appleton GVN, Owen RW, Wheeler EE, Challacombe DN, Williamson RCN. Effect of dietary calcium on the colonic luminal environment. Gut 1991; 32: 1374-7.

21 Thomas MG, Thomson JPS, Williamson RCN. Oral calcium inhibits rectal epithelial proliferation in familial adenomatous polyposis. Br f Surg 1993; 80: 499-502.

22 Lehy T, Mignon M, Abitbol JL. Epithelial cell proliferation in the rectal stump of patients with ileorectal anastomosis for ulcerative colitis. Gut 1983; 24: 1048-56.

23 Chen J, Compton C, Cheng E, Fromowitz F, Viola MV. $\mathrm{C}-\mathrm{Ki}$-ras mutations in dysplastic fields and cancers in ulcerative colitis. Gastroenterology 1992; 102: 1983-7.

24 Kragballe K, Beck HI, Sogaard H. Improvement of psoriasis by a topical vitamin $\mathrm{D}_{3}$ analogue $\mathrm{MC}-903$ in double-blind study. Br f Dermatol 1988; 119: 223-30.

25 Kragballe K. Treatment of psoriasis by the topical application of the novel cholecalciferol analogue calcipotriol (MC-903). Arch Dermatol 1989; 125: 1647-52.

26 Kragballe K, Gjertsen BT, De Hoop D, Karlsmark T, Van De Kerkhof PCM, Larko O, et al. Double-blind, right/left comparison of calcipotriol and betamethasone valerate in treatment of psoriasis vulgaris. Lancet 1991; 337: $193-6$.

27 Tsoukas CD, Provvedini DM, Manolagas SC. 1,25 Dihydroxyvitamin $\mathrm{D}_{3}$ : a novel immunoregulatory hormone. Science 1984; 224: 1438-40.

28 Provvedini DM, Tsoukas CD, Deftos LJ, Manolagas SC. 1,25 Dihydroxyvitamin $\mathrm{D}_{3}$ receptors in human leukocytes. Science 1983; 221: 1181-3.

29 Bhalla AK, Amento EP, Clemens TL, Holick MF, Krane SM. Specific high-affinity receptors for 1,25-dihydroxyvitamin $\mathrm{D}_{3}$ in human peripheral blood mononuclear cells: tamin $\mathrm{D}_{3}$ in human peripheral blood mononuclear cells: presence in monocytes and induction of T lymphocytes following

30 Bhalla AK, Amento EP, Krane SM. Differential effects of 1,25-dihydroxyvitamin $\mathrm{D}_{3}$ on human lymphocytes and monocyte/macrophages: inhibition of interleukin-2 and augmentation of interleukin-1 production. Cell Immunol 1986; 98: 311-22.

31 Rigby WFC, Stacy T, Fanger MW. Inhibition of T-lymphocyte mitogenesis by 1,25-dihydroxyvitamin $\mathrm{D}_{3}$ (calcitriol). 7 Clin Invest 1984; 74: 1451-5.

32 Giuliano AR, Franceschi R, Wood RI. Characterization of the vitamin $\mathrm{D}$ receptor from the Caco-2 human colon carthe vitamin $D$ receptor from the Caco-2 human colon carBiochem Biophys 1991; 2: 261-9. 